$\begin{array}{ll}\text { Volume } & : 04 \\ \text { Nomor } & : 03 \\ \text { Bulan } & : \text { September } \\ \text { Tahun } & : 2018 \\ \text { http } & : / / \text { jurnal.pps.ung.ac.id/index.php/AKSARA/index }\end{array}$

\title{
Model Pembelajaran Kooperatif Numbered-Head-Together Dalam Meningkatkan Hasil Belajar Siswa Pada Mata Pelajaran IPA
}

(Suatu Penelitian Dekripsi Pada Siswa Kelas VIII CC SMP Negeri 1 Kabila)

\author{
Yulirce Ngadju \\ SMP Negeri 1 Kabila \\ yulircengadju@gmail.com
}

\begin{abstract}
Abstrak
Pendidikan merupakan suatu tuntutan bagi setiap warga Negara, baik yang tua maupun yang masih muda. Penyelenggara pendidikan diharapkan dapat membekali setiap sumber daya manusia dengan pengetahuan, kecakapan dan keterampilan agar menjadi manusia yang berguna dikemudian hari. Selanjutnya dengan pendidikan tersebut akan menjadi motivasi bagi sumber daya manusia yang ingin mengembangkan dirinya, berpartisipasi secara aktuf, inovatif, dan produktif dalam pembangunan sesuai dengan kebutuhan dan harapan masyarakat

Untuk mencapai tujuan tersebut, telah diadakan berbagai perbaikan dan pembaharuan dalam sistem pendidikan yang mencakup semua komponen, antara lain: pengembangan kurikulum, peningkatan kualitas guru, peningkatan kualitas proses pembelajaran dan peningkatan kualitas anak didik

Pengembangan kurikulum merupakan hal yang sangat penting, untuk itu pemerintah saat ini sedang menerapkan Kurikulum Tingkat Satuan Pendidikan sebagai penyempurnaan kurikulum sebelumnya. Tujuan dari Kurikulum Tingkat Satuan pendidikan yakni ingin memusatkan diri pada pengembangan seluruh kompotensi siswa. Siswa dibuat agar kompotesinya muncul dan dikembangkan semaksimal mungkin melalui proses belajar mengajar. Selain kurikulum salah satu aspek yang turut menentukan peningkatan kualitas sumber daya manusia, terutama peningkatan kualitas pada anak didik yang antara lain meliputi faktor ketrampilan mengajar guru dalam hal penyampaian materi pelajaran.
\end{abstract}

\section{PENDAHULUAN}

Guru sebagai ujung tombak penyelenggara proses belajar mengajar di ekolah sebaiknya dapat melaksanakan tugasnya secara profesional. Profesionalisme yang dimaksud bukan hanya kemampuan membantu, membimbing dan mengarahkan, kemampuan mengajar, melatih dan mendidik akan tetapi lebih mengkhususkan lagi pada kemampuan merencanakan pembelajaran.

Dalam proses belajar mengajar banyak didominasi oleh kegiatan yang bersifat hafalan dan verbalistik. Sebagai akibatnya pemahaman siswa terhadap materi yang telah diajarkan sangat rendah. Untuk itu tugas utama guru adalah berupaya meningkatkan hasil belajar siswa dan mendorong siswa menemukan ideide baru yag menciptakan cara-cara baru dan hasil-hasil yang baru yang memberikan sumbangan yang berarti kepada pembangunan bangsa dan Negara untuk kesejahteraan dirinya, orang tua dan masyarakat

Penulis melihat bahwa dalam pelaksanaan proses belajar mengajar guru belum sepenuhnya memperhatikan gaya belajar siswa, sehingga pada gilirannya 


$\begin{array}{ll}\text { Volume } & : 04 \\ \text { Nomor } & : 03 \\ \text { Bulan } & : \text { September } \\ \text { Tahun } & : 2018 \\ \text { http } & : \text { //ejurnal.pps.ung.ac.id/index.php/AKSARA/index }\end{array}$

siswa hanya menonton guru, mendengarkan penjelasan guru dan sulit untuk mengemukakan ide-ide baru atau mengemukakan pendapat sebagai pikiran banding dari pendapat siswa lainnya serta penjelasan yang diberikan oleh guru pengajar. Dengan adanya situasi belajar yang seperti ini dapat mengakibatkan hasil belajar siswa rendah. Apabila hal ini dibiarkan tanpada adanya solusi pemecahannya, maka besar kemungkinan akan mengakibatkan rendahnya kualitas pendidikan sehingga mutu sumber daya manusia (SDM) menurun.

Pendekatan pengajaran kooperatif memiliki beberapa model pembelajaran dalam upaya meningkatkan hasil belajar siswa khususnya pada mata pelajaran IPA, salah satunya adalah model pembelajaran NHT (Numbered-Head-Together). NHTatau Penomoran-Berpikir-Bersama merupakan jenis pembelajaran kooperatif yang dirancang untuk mempengaruhi pola interaksi siswa dan sebagai struktur alternative terhadap struktur kelas tradisional

Dalam model pembelajaran (Numbered-Head-Together) NHT, keaktifan siswa sangat diperlukan. Karena model pembelajaran ini diwajibkan bagi setiap siswa untuk mengetahui isi materi yang dibahas, sehingga situasi di dalam kelas tidak hanya didominasi oleh siswa-siswa yang memiliki kemampuan di atas ratarata.

\section{KAJIAN TEORITIS}

\section{Hasil Belajar}

Kegiatan belajar mengajar terjadi karena adanya proses interaksi edukatif antara guru dan siswa di sekolah menghasilkan perubahan-perubahan di pihak siswa, yang sebelumnya belum pernah dimiliki, dan kemampuan-kemampuan itu dihasilkan karena usaha sendiri. Dengan kata lain bahwa hasil belajar adalah kemampuan yang dimiliki siswa berupa pengetahuan, sikap dan ketrampilan setelah menerima pengalaman belajarnya berinteraksi dengan lingkungannya. Jadi kemampuan yang diperoleh dari usaha belajar inilah yang disebut hasil belajar

Selain itu kegiatan belajar bertujuan untuk memperoleh perubahan tingkat laku, sehingga hasil belajar perubahan tingkah laku dalam perbuatan, reaksi, sikap, serta penambahan pengetahuan sebagai produk dari hasil belajar. Terbentuknya tingkah laku sebagai hasil mengajar mempunyai tiga ciri pokok yaitu: (1) tingkah laku tersebut berupa kemampuan actual, (2) kemampuan itu berlaku dalam waktu yang relative lama, dan (3) kemampuan baru diperoleh melalui usaha. Hasil belajar merupakan kapasitas yang terukur dari perubahan individu yang diinginkan berdasarkan ciri-ciri atau bawaannya melalui perlakuan pengajaran tertentu.

Hasil belajar siswa dapat mengukur tinggi rendahnya kemampuan belajarnya yang ditunjukkan adanya perubahan perilaku pada seseorang sebagai hasil pengalamannya. Hasil merupakan perilaku yang dapat diamati dan menunjukkan kemampuan yang dimilikinya oleh seseorang. Kemampuan siswa yang merupakan perubahan tingkah laku sebagai bukti hasil belajar itu dapat diklasifikasikan dalam dimensi-dimensi tertentu.

Berkaitan dengan hasil belajar ini Gagne membaginya dalam lima kelompok kemampuan yaitu informasi verbal, ketrampilan intelektual, strategi kognitif, ketrampilan motorik sikap. Kelima kemampuan tersebut di atas, yakni; (1) informasi verbal; yaitu kemampuan mendeskripsikan sesuatu dalam bentuk kata- 


$\begin{array}{ll}\text { Volume } & : 04 \\ \text { Nomor } & : 03 \\ \text { Bulan } & : \text { September } \\ \text { Tahun } & : 2018 \\ \text { http } & : / / \text { jurnal.pps.ung.ac.id/index.php/AKSARA/index }\end{array}$

kata dengan jalan mengatur informasi-informasi yang relevan, (2) ketrampilan intelektual yang berhubungan dengan prosedur yang mencakup belajar konsep, prinsip, diskriminasi dan pemecahan masalah, (3) strategi kognitif, yaitu kemampuan memecahkan masalah-masalah baru dengan jalan mengatur proses internal masing-masing individu dalam memperhatikan, mengingat, dan berpikir, (4) ketrampilan motoric, yaitu kemampuan untuk melaksanakan dan mengkoordinasikan gerakan-gerakan yang berhubungan dengan otot, (5) sikap, yaitu sesuatu kemampuan internal yang mempengaruhi tingkah laku seseorang dan didasaru oleh emosi, kepercayaan-kepercayaan serta faktor internal.

Dengan demikian hasil belajar merupakan perolehan dari suatu kegiatan belajar berupa kemampuan-kemampuan yang mengakibatkan perubahan tingkah laku dalam diri individu. Perubahan tingkah laku dapat diperlihatkan dalam bentuk tampilnya reaksi, sikap, perbuatan, ketrampilan dan pengetahuan

\section{Pembelajaran Kooperatif Kooperatif Numbered-Head-Together (NHT)}

Strategi number-head-together menekankan pada struktur ketrampilan sosial atau ketrampilan kelompok. Dalam hal ini ada 4 tahapan yang harus dilaksanakan oleh seseorang guru yang merupakan saintaks dari strategi numberhead-together.

\section{METODE PENELITIAN}

Penelitian ini direncanakan akan dilaksanakan di kelas VIII C SMP Negeri 1 Kabila tahun pelajaran 2016/2017 dengan jumlah siswa 30 orang yang terdiri dari 15 siswa laki-laki dan 23 siswa perempuan

Dalam rangka pelaksanaan tindakan kelas ini dilaksanakan persapanpersiapan sebagai berikut:

1. Melaporkan dan meminta izin kepada kepala sekolahserta mengkonsultasikan tentang guru yang menjadi mitra kerja

2. Mengadakan observasi dalam rangka mengidentifikasi masalah

3. Menganalisis pokok permasalahan yang menjadi subjek penelitian

4. Mendesain scenario pembelajaran sesuai dengan pemecahan masalah yang telah ditetapkan

5. Mempersiapkan format observasi

6. Menetapkan waktu pelaksanaan tindakan

Untuk mengetahui tingkat keberhasilan pencapaian tindakan ini dirumuskan kriteria sebagai berikut:

1. Kegiatan belajar mengajar yang dinilai melalui lembar observasi berupa cek list

2. Tes terdiri dari pres-test dan post-test yang dibuat oleh peneliti sendiri yang bertujuan untuk mengetahui keberhasilan siswa dalam pencapaian indikator

3. Standart ketuntasan minimal hasil belajar siswa secara indivual adalah 68 dan secara klasikal minimal $65 \%$

\section{Tahap Pemantauan dan Evaluasi}

Pada tahap ini dilaksanakan observasi dan evaluasi terhadap pelaksanaan tindakan dengan menggunakan lembar observasi yang telah dibuat 


$\begin{array}{ll}\text { Volume } & : 04 \\ \text { Nomor } & : 03 \\ \text { Bulan } & : \text { September } \\ \text { Tahun } & : 2018 \\ \text { http } & : / / \text { jurnal.pps.ung.ac.id/index.php/AKSARA/index }\end{array}$

\section{Tahap analisis dan Refleksi}

Analisis dialkukan dengan melihat hasil observasi yang dilakukan didalam pembelajaran dan refleksi dilaksanakan pada akhir siklus untuk memperbaiki dan meningkatkan hasil yang ingin dicapai pada siklus sebelumnya

Salah satu aspek yang paling penting dalam penelitian tindakan kelas adalah tahap analisis data. Analisis data ini dilaksanakan secara bertahap dan berkesinambungan disetiap akhir siklus. Data yang diperoleh berupa data hasil pengamatan kegiatan guru dan data aktivitas siswa, serta data hasil belajar siswa.

\section{HASIL PENELITIAN DAN PEMBAHASAN Deskripsi Hasil Penelitian Persiapan}

Penelitian ini merupakan penelitian tindakan kelas yang telah berlangsung dalam dua siklus pembelajaran. Setiap tindakan dilaksanakan berdasarkan sistem yang berlaku dan mengehndaki adanya perubahan hingga mencapai kriteria yang telah ditetapkan, dan permasalahannya difokuskan pada peningkatan hasil belajar siswa pada mata pelajaran IPA dengan menggunakan model pembelajaran kooperatif Numbered-Head-Together (NHT) dengan menggunakan format-format sebagai berikut

1. Lembar observasi berupa hasil pengamatan kegiatan belajar mengajar

2. Daftar nilai hasil belajar siswa dengan pemberian tes

3. Daftar informasi balikan siswa

4.1.2 Proses Pelaksanaan Tindakan

Adapun proses pelaksanaan tindakan kelas dpaat diuraikan sebagai berikut:

a. Kegiatan pendahuluan

- Memberikan pre-test pada awal pembelajaran

- Guru menyampaikan indikator, tujuan dan manfaat pembelajaran

- Guru menggali pengatahuan prasyarat dengan menanyakan materi sebelumnya

- Guru memberikan motivasi dengan mengaitkan materi pada kehidupan nyata

b. Kegiatan inti

- Guru mengorganisasikan siswa kedalam kelompok kooperatif (cooperative Learning Numbered-Head-Together NHT)

- Guru membagikan materi dan kartu identitas kelompok

- Guru mengarahkan siswa untuk berdiskusi kelompok dan memecahkan kesulitan-kesulitan yang dihadapi

c. Kegiatan penutup

- Guru mengarahkan siswa untuk membuat kesimpulan dari hasil diskusi

- Memberikan evaluasi untuk mengukur keberhasilan tindakan

- Memberikan penghargaan kepada kelompok yang memiliki kinerja tinggi

Deskripsi hasil tindakan

1. Hasil Observasi Kegiatan Pembelajaran

Pelaksanaan penelitian ini diadakan dikelas VIII C SMP Negeri 1 Kabila dengan jumlah siswa 30 orang. Pengamatan pada proses belajar mengajar yang 


$\begin{array}{ll}\text { Volume } & : 04 \\ \text { Nomor } & : 03 \\ \text { Bulan } & : \text { September } \\ \text { Tahun } & : 2018 \\ \text { http } & : / / \text { jurnal.pps.ung.ac.id/index.php/AKSARA/index }\end{array}$

dilakukan pengamat dapat terlihat pada hasil pemantauan terhadap kegiatan belajar mengajar. Pada proses pembelajaran ada 17 aspek kegiatan guru dan7 aspek kegiatan siswa yang diamati. Setiap aspek dinilai dengan menggunakan kategori sangat baik (SB), baik (B), cukup (C), dan kurang (K). Hasil pengamatan terhadap kegiatan yang dilakukan guru yang dapat dilihat pada table di bawah ini: dan diawali dengan pre-test yaitu sebagai berikut:

Tabel 1. Pre-test

\begin{tabular}{|l|c|c|c|}
\hline \multicolumn{1}{|c|}{ Nilai } & Jumlah siswa & Presentase $(\%)$ & Ket \\
\hline 68 ke atas & 6 & 20 & - \\
\hline 68 ke bawah & 24 & 80 & - \\
\hline
\end{tabular}

1. Kegiatan Belajar Mengajar

Untuk melihat hasil pengmatan kegiatan belajar mengajar dapat dilihat pada tabel dibawah ini :

Tabel 2. Hasil Pengamatan Kegiatan Guru Pada Siklus 2

\begin{tabular}{|l|c|c|c|c|}
\hline \multicolumn{1}{|c|}{ Aspek yang diamati } & Sangat baik & Baik & Cukup & Kurang \\
\hline Jumlah aspek & 3 & 14 & - & - \\
\hline Prosentase (\%) & 17,64 & 82,35 & - & - \\
\hline
\end{tabular}

Tabel 3. Hasil pengamatan kegiatan siswa pada siklus 2

\begin{tabular}{|l|c|c|c|c|}
\hline \multicolumn{1}{|c|}{ Aspek yang diamati } & Sangat baik & Baik & Cukup & Kurang \\
\hline Jumlah aspek & 3 & 4 & - & - \\
\hline Prosentase (\%) & 42,86 & 57,14 & - & - \\
\hline
\end{tabular}

2. Hasil Belajar

Hasil siklus ini pun sleain dilihat pada hasil observasi pemantauan kegiatan belajar mengajar juga ditinjau dari nilai yang diperoleh siswa setelah diberikan tes hasil belajar berupa post-test. Untuk nilai hasil belajar ini selengkapnya dapat dilihat pada tabel dibawah ini:

Tabel 4. Post - test

\begin{tabular}{|l|c|c|c|}
\hline \multicolumn{1}{|c|}{ Nilai } & Jumlah siswa & Presentase $(\%)$ & Ket \\
\hline 68 ke atas & 24 & 80 & - \\
\hline 68 ke bawah & 6 & 20 & - \\
\hline
\end{tabular}

Selanjutnya nilai tes hasil belajar dapat dilihat pada lampiran 8

Memperhatikan hasil tes belajar siswa pada siklus ini maka hasil belajar siswa sudah mencapai target seperti pada indikator yaitu secara klasikal siswa dikatakan tuntas belajar minimal 65\% dari jumlah siswa telah memperoleh nilai 68 ke atas.

\section{Pembahasan}

Dari hasil pelaksanaan tindakan kelas, telah Nampak adanya peningkatan pemahaman siswa terahdap materi yang diberikan. Hasil belajar ini merupakan efek dari penggunaan model pembelajaran kooperatif Numbered-Head-Together. Dengan model pembelajaran ini siswa termotivasi untuk belajar, berupaya berpikir kritis terhadap satu masalah dan siswa cenderung memberikan yang terbaik untuk kelompoknya dalam memecahkan masalah. Dan dalam model pembelajaran ini guru dalam proses belajar mengajar hanya bertugas sebagai pengarah, bukan 


$\begin{array}{ll}\text { Volume } & : 04 \\ \text { Nomor } & : 03 \\ \text { Bulan } & : \text { September } \\ \text { Tahun } & : 2018 \\ \text { http } & : / / \text { jurnal.pps.ung.ac.id/index.php/AKSARA/index }\end{array}$

pengajar sehingga aktivitas yang terjadi dalam kelas adalah atas inisiatif dari siswa dan diarahkan oleh guru.

Hal ini dapat dilihat dari data hasil penelitian yang dilaksanakan yaitu baik itu kegiatan guru, siswa maupun haisl belajar siswa itu sendiri. Hal ini terlihat pada pengamatan terhadap kegiatan guru dari 17 aspek yang diamati diperoleh kualifikasi sangat baik menjadi 4 aspek dan kualifikasi baik 13 aspek. Pengamatan terhadap kegiatan siswa dari 7 aspek yang diamati diperoleh kualifikasi sangat baik 3 aspek dan kualifikasi baik 4 aspek. Sedangkan untuk hasil belajar siswa, yang memperoleh nilai kurang dari 68 adalah tinggal 6 orang siswa saja dan siswa yang memperoleh nilai minimal 68 ada 24 siswa, dan daya serap siswa pun mencapai $76,63 \%$.

Dari data penelitian yang diperoleh di atas menunjukkan bahwa penggunaan model pembelajaran kooperatif Numbered-Head-Together ini dapat merangsang pola berpikir siswa, dengan mempelajar materi secara mandiri, kemudian membahas materi dengan sesama kelompok ahli dan menjelaskan kembali materi tersebut kepada teman kelompok. Hal-hal tersebut merupakan efek langsung dari pengaruh model pembelajaran kooperatif Numbered-Head-Together. Pada mata pelajaran yang akhirnya bisa meningkatkan hasil belajar siswa itu sendiri.

\section{PENUTUP}

Penggunaan model pembelajaran kooperatif Numbered-Head-Together dalam proses belajar mengajar sesuai dengan penelitian tindakan kelas pada kelas VIII C SMP Negeri 1 Kabila telah menunjukan peningkatan hasil belajar siswa baik secara individual maupun secara klasikal yang cukup signifikasn yaitu secara klasikal dari 30 siswa yang memperoleh nilai minimal 68 ada 24 atau mencapai $80 \%$

\section{DAFTAR PUSTAKA}

Ahmad Rokhmad,1979. Belajar dan Pembelajaran. Bandung: Remaja Rosdakarya Dahar, Ratna Wilis, 1998 Teori-Teori Belajar, Jakarta; Depdikbud Djamarah Syaiful Bahri, 2002 Psikologi Belajar, Jakarta PT. Adi Mahsatya Hamalik, Oemar, 1983. Belajar dan Kesulitan-kesulitan Belajar, Jakarta; Rineka Cipta

M.Nur.1996. Pembelajaran Kooperatif, Surabaya : IKIP Surabaya

Nasution,1984. Kurikulum Dan Pengajaran, Jakarta : Bina Aksara

Silverius, Suke. 1991. Evaluasi Hasil belajar dan Umpan Balik, Jakarta; Gramedia Widiasarana Indonesia

Sudajana, Nana, 1999. Penilaian Hasil Proses Belajar Mengajar, Bandung; PT Remaja Rosdakarya

Sudibyo, Elok 2004. Teori teori Belajar yang melandasi model pembelajaran, Jakarta:Depdiknas

Uno, Hamzah 1999. Teori Belajar dan pembelajaran. Gorontalo. Nurul Janna

Winkel W.S 1996. Psikolog Pengajaran, Jakarta : PT Gramedia Widiasarana Indonesia 